\title{
Case Report: Rare case of Idiopathic primary hypoparathyroidism can rarely present as focal seizures in neonates
}

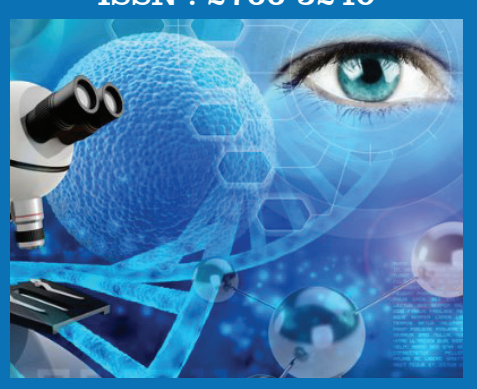

Issue Type: Volume 2 Issue 2
Author Name:

Dr. Hamad F. Al-Sanea M.D.

Department of surgery Farwaniya hospital. Ministry of Health Kuwait

Corresponding Author:

Dr. Hamad F. Al-Sanea M.D.

Citation: Dr. Hamad F. Al-Sanea M.D., Rare case of Idiopathic primary hypoparathyroidism can rarely present as focal seizures in neonates

Received Date: 2nd Feb 2022

Published Date: 16th Feb 2022

Copyrights: Dr. Hamad F. Al-Sanea M.D. This is an open access article distributed under the Creative Commons Attribution License, which permits unrestricted use, distribution, and reproduction in any medium, provided the original work is properly cited.

\section{ABSTRACT}

Hypoparathyroidism is a rare disorder in which the body is not able to produce enough parathyroid hormone (PTH),which is necessary to control the levels of calcium and phosphate ions. Decreased levels of PTH lead to low levels of calcium and high levels of phosphate in the blood.

Calcium is important electrolyte for muscle contractions and release of messengers from the nerves cells, so people with hypocalcemia experience seizures, which involve large amounts of activity in both muscles and nerves.

\section{Introduction:}

Seizure in neonatal period has very wide etiology with different management and prognosis, hypocalcemia is one of treatable metabolic causes with good prognosis(1).hypoparathyrodiam is rare cause of late onset hypocalcemia. Although, having a focal seizure in neonatal due to endocrinology disorder is very rare(2).in this interesting case of a 35 day-old female neonate who presented with second time left - sided focal fits. Initial laboratory workup revealed hypocalcemia, with all other electrolytes in their normal ranges. Further diagnostic workup revealed low levels of parathyroid hormone, thereby unmasking a diagnosis of idiopathic primary hypoparathyroidism presenting as late-onset hypocalcemic fits.

KeyWords: Neonate, seizure, Hypocalcaemia, Hypoparathyroidism, Hyperphosphatemia

\section{Case report:}

35 days old neonate baby girl know presented with recurrent focal seizure unilateral left leg jerky movement lasting for few seconds associated with loud abnormal crying and face turning to blue, no LOC, No dropping saliva, no unrolling eyes, the baby is full term, the baby is product of consanguineous marriage, the baby was full term, NVD in hospital, no complications during the delivery

On examination she was fine, Vital signs were within normal limits, systemic examination unremarkable and no dysmorphic features. Focal seizures were observed characterized by, jerky movements of the left foot and were controlled with Calcium gluconate and 1 alpha drops,

Results of investigations revealed normal blood counts, Renal function tests, blood glucose, electrolytes and $\mathrm{C}$ reactive protein but hypocalcemia was noted (1.79). Intravenous calcium replacement was done and seizure stopped. He remained well for 24 hours and again started having seizures. Again metabolic screening (blood glucose, calcium, magnesium, electrolytes) Inborn error of metabolism screening (ABGs, lactate and ammonia) and Ultrasonography brain were done. Again it revealed hypocalcemia. To find out the cause of persistant hypocalcemia, further laboratory workup (phosphate, alkaline phosphatase, vit D and PTH levels) was done. It was suggestive of hypoparathyroidism. X-Ray chest and Echocardiography were done to rule out DieGorge syndrome. Maternal bone profile and PTH level were within normal limits. A final diagnosis of congenital primary hypoparathyroidism was made and patient managed with I/V calcium and oral cholecalciferol. Seizures seized completely and on 7th day of hospitalization patient was discharged on oral medication (calcium and cholecalciferol) with follow up advice. At 6 month follow up he is thriving well with no evidence of nephrocalcinosis or any other complication and metabolic profile is within normal range. 


\begin{tabular}{|c|c|c|c|c|c|}
\hline \multicolumn{6}{|c|}{ PATIENT CUMULATIVE REPORT } \\
\hline Test Description & $\begin{array}{l}0441020221 \\
04: 37: 36 \\
2102913584\end{array}$ & $\begin{array}{l}\text { 0311012021 } \\
20: 15: 40 \\
21029292900\end{array}$ & $\begin{array}{l}\text { 03/110202021 } \\
\text { 12:45:06 } \\
\text { 21029121140 }\end{array}$ & Reference & Unit \\
\hline $\begin{array}{l}\text { eGFR (Calculated) } \\
\text { Glucose }\end{array}$ & $\begin{array}{l}166 \\
4.05 \mathrm{~L}\end{array}$ & & $\begin{array}{l}179 \\
4.81\end{array}$ & & \\
\hline & $0.9 \mathrm{~L}$ & & 1.8 & 1.8-6.4. & minolL \\
\hline $\begin{array}{l}\text { Creatinie } \\
\text { Phosphorus }\end{array}$ & ${ }_{30}^{40} \mathrm{H}$ & & $32 \mathrm{~L}$ & $35-62$ & umoll \\
\hline Magnesium & 0.73 & $\begin{array}{l}0.9 .9 \mathrm{H} \\
0.67 \mathrm{~L}\end{array}$ & & $\begin{array}{l}1.159-2.215 \\
0.7-1.03\end{array}$ & $\begin{array}{l}\text { mmolL } \\
\text { momolL }\end{array}$ \\
\hline Calcium & $1.94 \mathrm{~L}$ & $1.72 \mathrm{~L}$ & $1.61 \mathrm{~L}$ & 1.96-2.66 & mmol/L \\
\hline Sodium & 143 & & $135 \mathrm{~L}$ & $136-146$ & mmoll \\
\hline $\begin{array}{l}\text { Potassium } \\
\text { Chloride }\end{array}$ & $5.6 \mathrm{H}$ & & 5.2 & 3.5 .5 .2 & mmol/L \\
\hline $\begin{array}{l}\begin{array}{l}\text { Chloride } \\
\text { Bicarbonate }\end{array} \\
\text { a }\end{array}$ & $\begin{array}{l}107 \mathrm{H} \\
15.5\end{array}$ & & $\begin{array}{l}98 \\
20.5\end{array}$ & $\begin{array}{l}{ }_{136-126}^{9} \\
1329\end{array}$ & $\begin{array}{c}\text { mmoll. } \\
\text { mmolh }\end{array}$ \\
\hline $\begin{array}{l}\text { Albumin } \\
\text { Alunin }\end{array}$ & $34 \mathrm{~L}$ & $31 \mathrm{~L}$ & $33 \mathrm{~L}$ & 35.50 & $\begin{array}{l}\text { gil } \\
\mathrm{g} / \mathrm{L}\end{array}$ \\
\hline $\begin{array}{l}\text { Allakaline Phosphatase } \\
\text { ALT }\end{array}$ & ${ }_{26}^{30} \mathrm{H}$ & $571 \mathrm{H}$ & & 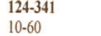 & $\begin{array}{l}\text { IU/L } \\
\text { IUL }\end{array}$ \\
\hline AST & & & & $10-42$ & IUh \\
\hline $\begin{array}{l}\text { T.B.Biliturinu } \\
\text { D.BBiritubuin }\end{array}$ & $\begin{array}{l}28.3 \mathrm{H} \\
16.4 \mathrm{H}\end{array}$ & & & $\begin{array}{l}3.20 \\
0.5 \\
3\end{array}$ & $\begin{array}{l}\text { unolh } \\
\text { umol/h }\end{array}$ \\
\hline $\begin{array}{l}\text { Anion Gap } \\
\text { Adjusted Calcium }\end{array}$ & 26 & $1.94 \mathrm{~L}$ & $\begin{array}{l}22 \\
1.79 \mathrm{~L}\end{array}$ & $1.96-2.66$ & $\begin{array}{l}\text { mmollh } \\
\text { mmoll. }\end{array}$ \\
\hline
\end{tabular}

Figure (1):Patient renal function test and bone profile results

\section{Discussion:}

Hypoparathyroidism is a disease characterized by low circulating concentrations of parathyroid hormone (PTH) resulting in low calcium levels and increased phosphate levels in the blood enhance neuromascular irritability due to low level of calcium causing muscles cramps and seizures(3). Hypocalcemia May lead to serious complications complication that can lead to arrhythmia, heart failure and seizure (4). Seizure occurs in hypocalecmia patient as a result of stimulating neuronal excitability due to reduced extracellular concentration of calcium rather than depleted intracellular levels (5).Neonatal hypocalcemia is defined when total serum calcium levels of less than $7 \mathrm{mg} / \mathrm{dL}$ (6) In our patient Late hypocalcemia is defined as hypocalcemia occurring after the third day of life.This is a rare condition and one of it's causes is hypoparathyrodiam (7).

In our patient,maternal parathyroid hormone (PTH) normal, serum calcium, Magnesium and PTH were low, while phosphorus was high ultimately lead to diagnose the patient by left sided focal fits secondary to hypoparathyrodiam.Our patient received breast milk and formula without high phosphate content. Excessive phosphate intact suppress PTH and has been revived in patient receiving COW milk based formula (8). The possibility of having Di-George syndrome as it is usually linked to congenital hypoparathyrodiam (9), was ruled out by CT scan that showed intact thymus and parathyroid.

To address the symptomatic hypocalcemia and increasing focal fits, treatment with alfacalcidol and calcium carbonate was initiated.which the seizures halted, and a 3- month followup showed no complications. Other study 28-day neonate had a similar therapeutic regimen with good outcome (11).Our treatment Protocol was based on these two cases (10-11).

\section{Conclusion:}

Idiopathic primary hypoparathyroidism can rarely present as focal seizures in neonates that can be successfully treated with calcium and vitamin D3 supplements. However, the data pertaining to the utility and efficacy of such regimens remains informal and based on personal experiences. There is a need for appropriate treatment guidelines to be organized for the management of similar cases in order to avoid complications and patient mortality.

\section{Reference:}

1. Kossoff EH, Silivia MT, Maret A, Carakushansky M, Vining EP. Neonatal hypocalcaemic seizures: case report and literature review. J Child Neurol. 2002;17:236-239. doi: 10.1177/088307380201700319.

2. Neonatal idiopathic primary hypoparathyroidism: a rare cause of neonatal seizures. Hussain S, Sabir MU, Ali M, Shah SA. Pak J Med Sci. 2015;31:1277-1279.

3. Hypoparathyroidism. Mannstadt M, Bilezikian JP, Thakker RV, et al. Nat Rev Dis Primers. 2017;3:17055.

4.Endocr Connect. 2018 Oct; 7(10): 1067-1074.

5. R. Nardone, F. Brigo, and E. Trinka, "Acute symptomatic seizures caused by electrolyte disturbances," Journal of Clinical Neurology, vol. 12, no. 1, pp. 21-33, 2016. View at: Publisher Site | Google Scholar

6. Hypocalcemia in the newborn. Jain A, Agarwal R, Sankar MJ, Deorari A, Paul VK. Indian J Pediatr. 2010;77:1123-1128. [PubMed] [Google Scholar]

7. Jain A, Agarwal R, Sankar MJ, Deorari A, Paul VK. Hypocalcemia in the Newborn. Indian J Pediatr. 2010;77:11231128. [PubMed] [Google Scholar]

8. Lytt I. Gardner, Elsie A. Maclachlan, Walter Pick, Mary L. Terry And Allan M. Butler Pediatrics February 1950, 5 (2) 228240

9. Clinical approach to hypocalcemia in newborn period and infancy: who should be treated? Vuralli D. Int J Pediatr. 2019;2019:4318075. [PMC free article] [PubMed] [Google Scholar]

10. Neonatal idiopathic primary hypoparathyroidism: a rare cause of neonatal seizures. Hussain S, Sabir MU, Ali M, Shah SA. Pak J Med Sci. 2015;31:1277-1279. [PMC free article] [PubMed] [Google Scholar] discuss

11. An unusual case of neonatal seizures as manifestation of asymptomatic maternal hypoparathyroidism. LK P, Kannan PR, Shanbhag M. BMJ Case Rep. 2019;12:0. [PMC free article] [PubMed] [Google Scholar] discuss 